\title{
Inhibitory effect of TGF- $\beta 1$ on NO production in peritoneal macrophages from collagen-induced arthritis rats involving the LPS-TLR4 pathway
}

\author{
TING-YU WANG ${ }^{1,2}$, JUN LI ${ }^{2}$, ZHIGUI JIN ${ }^{1}$, FEIHUA WU ${ }^{1}$ and QIAN ZHOU ${ }^{2}$ \\ ${ }^{1}$ Department of Pharmacy, Shanghai Ninth People's Hospital, Shanghai Jiaotong University School of Medicine, \\ Shanghai 200011; ${ }^{2}$ School of Pharmacy, Anhui Medical University, Hefei, Anhui 230032, P.R. China
}

Received February 2, 2013; Accepted July 8, 2013

DOI: $10.3892 / \mathrm{mmr} .2013 .1641$

\begin{abstract}
Transforming growth factor- $\beta 1$ (TGF- $\beta 1$ ) is critical in controlling inflammatory responses and the prevention of autoimmune diseases. Although the effect of TGF- $\beta 1$ on macrophages from normal mice or rats has been established, little attention has been paid to its effect on disease conditions. In the present study, we investigated the regulatory effect, and possible mechanism, of TGF- $\beta 1$ exposure on the secretion of nitric oxide (NO) in peritoneal macrophages (PMФ) obtained from collagen-induced arthritis (CIA) rats. The CIA model was established by immunizing the emulsion of collagen type II and incomplete Freund's adjuvant (IFA) in Wistar rats. PM $\Phi$ were incubated with TGF- $\beta 1(5 \mathrm{ng} / \mathrm{ml})$ for $36 \mathrm{~h}$ and the supernatant, and cell mRNA and protein were collected. NO concentration was determined using an NO assay kit. The mRNA expression of inducible nitric oxide synthase (iNOS) and Toll-like receptor 4 (TLR4) was determined using reverse transcription-polymerase chain reaction (RT-PCR). The protein expression of iNOS was tested with western blot analysis. The expression of membrane TLR4 was determined by flow cytometry. We discovered that the secretion of NO from the PMФ of CIA rats increased compared with normal rats. TGF- $\beta 1$ significantly inhibited the production of NO in the PM $\Phi$ from CIA rats. iNOS mRNA and protein expression in the PMФ from CIA rats may be suppressed by TGF- $\beta 1$. TLR4 mRNA and protein expression in PMФ from CIA rats were upregulated with LPS stimulation and treatment with TGF- $\beta 1$ inhibited their expression. These results demonstrated that TGF- $\beta 1$ inhibited lipopolysaccharide (LPS)-induced NO production in the PM $\Phi$ from CIA rats, which may be due to the inhibition of the LPS-TLR4 signaling pathway.
\end{abstract}

Correspondence to: Professor Jun Li, School of Pharmacy, Anhui Medical University, Hefei, Anhui 230032, P.R. China

E-mail: aydlijun@sohu.com

Key words: TGF- $\beta 1$, nitric oxide, macrophages, arthritis, TLR4

\section{Introduction}

Three transforming growth factor- $\beta$ (TGF- $\beta$ ) isoforms, TGF- $\beta 1$, TGF- $\beta 2$ and TGF- $\beta 3$, have been identified in mammals. They have similar biological functions, even though they are expressed in different tissues (1). TGF- $\beta$ is synthesized in its inactive form containing TGF- $\beta$, the dimeric proprotein, known as the latency-associated peptide (LAP), and the latent TGF- $\beta$ binding protein (LTBP) $(2,3)$. Under physiological conditions, with additional stimuli such as a low $\mathrm{pH}$ and proteolysis, active TGF- $\beta$ is liberated from the LTBP/LAP/TGF- $\beta$ complex either in a membrane-bound or soluble form. The active form of TGF- $\beta$ exerts its functions by binding to its receptor on the cell surface (4-7).

Amongst the three isoforms, the pleiotropic cytokine TGF- $\beta 1$ is produced by a number of cells, including macrophages, epithelial cells, fibroblasts and eosinophils. It is a regulatory molecule with an effect on various biological processes such as growth, development, tissue homeostasis and regulation of the immune system (8). The pivotal role of TGF- $\beta 1$ within the immune system is to maintain tolerance via the regulation of lymphocyte proliferation, differentiation and survival. TGF- $\beta 1$ prevents the development of autoimmune diseases without compromising immune responses to pathogens (9). TGF- $\beta 1$ has been considered to be a major anti-inflammatory cytokine; it also exerts proinflammatory properties depending on the cell type, tissue of origin or a variety of other factors (10). Based on the data obtained from transgenic mice lacking TGF- $\beta 1$, the predominant role of TGF- $\beta 1$ in vivo is in anti-inflammation and immune suppression (11,12). Furthermore, TGF- $\beta 1$ controls the initiation and resolution of inflammatory responses through the regulation of chemotaxis and activation of leukocytes in the periphery (9).

Rheumatoid arthritis (RA) is an inflammatory autoimmune disease that affects $\sim 1 \%$ of the population worldwide. It is characterized by the chronic and persistent inflammation of the synovium and the progressive erosion of cartilage and bone (13). The correlation between the TGF- $\beta 1$ serum levels and the functional class in RA has been demonstrated (14). Kim et al revealed that TGF- $\beta 1$ polymorphism determines the progression of joint destruction in RA (15). TGF- $\beta 1$ mRNA was expressed in the synovial tissues 
in RA patients and streptococcal cell wall (SCW)-induced arthritic rats. TGF- $\beta 1$ was secreted in vitro by synovial tissue explants and fibroblast-like synovial cells (FLSs). Moreover, the growth of FLS from RA patients and SCW rats in vitro is inhibited by TGF- $\beta 1(16)$. $\mathrm{CD} 4{ }^{+} \mathrm{CD} 25^{+}$regulatory $\mathrm{T}$ cells $\left(\mathrm{CD} 4{ }^{+} \mathrm{CD} 25^{+}\right.$Tregs), a potential cell therapy for RA, may be induced by TGF- $\beta 1$ from naive T cells. Furthermore, $\mathrm{CD} 4{ }^{+} \mathrm{CD} 25^{+}$Tregs suppress effective cells through the release of TGF- $\beta 1$ (17). Our previous study revealed that the anti-arthritic drug leflunomide upregulated $\mathrm{CD} 4{ }^{+} \mathrm{CD} 25^{+}$Tregs in collagen-induced arthritis (CIA) rats, which correlated with the enhanced expression and secretion of TGF- $\beta 1$ (18).

In order to gain further understanding of the role of TGF- $\beta 1$ in its anti-inflammatory function, we established the rat CIA model and examined the effect of TGF- $\beta 1$ on peritoneal macrophages (PMФ) obtained from the CIA rats. Furthermore, the critical role of the lipopolysaccharide (LPS)-Toll-like receptor 4 (TLR4) cell signaling pathway on the inhibitory effect of TGF- $\beta 1$ was investigated. Clarifying the processes of macrophage activation in RA is useful for tracing the therapeutic target molecule to reduce inflammation and the resultant joint injury in rheumatoid diseases.

\section{Materials and methods}

Reagents. Bovine type II collagen (CII), incomplete Freund's adjuvant (IFA) and LPS (Escherichia coli serotype 055:B5) were purchased from Sigma-Aldrich (St. Louis, MO, USA). The RPMI-1640 medium from Gibco Co. (Carlsbad, CA, USA, pH 7.2) was supplemented with HEPES $25 \mathrm{mmol} / \mathrm{l}$, L-glutamine $2 \mathrm{mmol} / \mathrm{l}, 2$-mercaptoethanol $50 \mu \mathrm{mol} / 1$, penicillin sodium $100 \mathrm{IU} / 1$, streptomycin $100 \mathrm{IU} / 1$ and sodium pyruvate $1 \mathrm{mmol} / \mathrm{l}$ with $\mathrm{pH}$ 7.2. Recombinant human TGF- $\beta 1$ was purchased from Life Technologies (Grand Island, NY, USA). Inducible nitric oxide synthase (iNOS), TLR4 and $\beta$-actin primers were produced by Shanghai Sangon Biological and Technological Company (Shanghai, China). Total RNA isolation system and reverse transcription polymerase chain reaction (RT-PCR) system were purchased from Promega (Madison, WI, USA). Rabbit polyclonal iNOS antibody, TLR4 $\mathrm{mAb}$ and $\beta$-actin $\mathrm{mAb}$ were purchased from Santa Cruz Biotechnology (Santa Cruz, CA, USA). SuperSignal West Femto Maximum Sensitivity Substrate 34094 was purchased from Pierce Biotechnology, Inc. (Rockford, IL, USA). The nitric oxide (NO) reagent kit was obtained from the Nanjing Jiancheng Bioengineering Institute (Nanjing, China).

Animals. Wistar rats (male, 110-130 g) were purchased from the Experimental Animal Center of Anhui Medical University. They were housed in standard cages at a constant temperature of $22 \pm 1^{\circ} \mathrm{C}, 55 \pm 5 \%$ relative humidity with a natural dark-light cycle for 1 week prior to the start of the experiment. The animals had free access to food and tap water. The experimental animal protocol was approved by the Anhui Medical University Animal Care and Use Committee. The study was approved by the Ethics Committee of Shanghai Jiao Tong University School of Medicine, Shanghai Ninth People's Hospital, Shanghai, China.
Establishment of CIA. CII was dissolved in a $0.1 \mathrm{M}$ acetic acid solution at $2 \mathrm{mg} / \mathrm{ml}$ by stirring overnight at $4^{\circ} \mathrm{C}$. The dissolved CII was emulsified with an equal volume of IFA. On day 0 , rats were injected intradermally with $0.5 \mathrm{ml}$ of the emulsion (containing $0.5 \mathrm{mg}$ of $\mathrm{CII}$ ) at the base of the tail and 3-5 additional sites on the back (18). Seven days later, a second injection of CII in IFA was administered in the same way.

Preparation of $P M \Phi$. On day 18 , following immunization, rats were sacrificed by bleeding. РМФ $(1 \mathrm{ml}$, concentration of $2 \times 10^{6} \mathrm{cell} / \mathrm{s} / \mathrm{ml}$ ) were collected and cultured in a 24 -well culture plate. Following $2 \mathrm{~h}$ of pre-incubation, non-adherent cells were removed by washing twice with cool PBS. The monolayer of PM $\Phi$ was obtained and identified by anti-CD68 mAb with $>90 \%$ staining. РM $\Phi$ were stimulated by LPS $(3 \mu \mathrm{g} / \mathrm{ml})$ with or without TGF- $\beta 1(5 \mathrm{ng} / \mathrm{ml})$ for $36 \mathrm{~h}$. Following centrifugation at $500 \mathrm{x}$ g for $10 \mathrm{~min}$, all supernatants containing NO were collected and stored at $-20^{\circ} \mathrm{C}$ until assay. The remaining cells were collected for mRNA and protein determination.

Determination of cell viability. Primary cultured rat $\mathrm{PM} \Phi$ were grown in 96-well plates at a concentration of $5 \times 10^{4}$ cells/well followed by treatments for various times. To measure cell viability, $10 \mu \mathrm{l}$ of $5 \mathrm{mg} / \mathrm{ml}$ 3-(4,5-dimethyl-2-thiazolyl)2,5diphenyl-2H-tetrazolium bromide (MTT) in growth medium was added to each well. Following incubation with MTT for $4 \mathrm{~h}$ at $37^{\circ} \mathrm{C}$, the cell medium was removed. The precipitated formazan, a product of the MTT tetrazolium ring by the action of mitochondrial dehydrogenases, was dissolved with DMSO and the absorbance (A) was quantified spectrophotometrically at $570 \mathrm{~nm}$. In addition to the drug treatment wells (served as sample wells), blank wells with no cells and control wells with vehicle treatment were set up at the same time. Cell viability was calculated as: $\left(\mathrm{A}_{\text {sample }}-\mathrm{A}_{\text {blank }}\right) /\left(\mathrm{A}_{\text {control }}-\mathrm{A}_{\text {blank }}\right)$ x 100 .

NO assay. NO concentration was determined using a NO reagent kit according to the manufacturer's instructions.

$R T-P C R$. Total RNA was extracted from rat spleen lymphocyte using TRIzol reagent (Invitrogen Life Technologies, Carlsbad, CA, USA) according to the manufacturer's instructions. The first strand of cDNA was synthesized using total RNA $(1 \mu \mathrm{g} / \mathrm{reac}-$ tion) incubated at $70^{\circ} \mathrm{C}$ for $10 \mathrm{~min}$ and immediately cooled on ice. $\mathrm{MgCl}_{2}(4 \mu \mathrm{l}$ of $2 \mathrm{mM}), 2 \mu \mathrm{l}$ of reverse transcription 10X buffer, $2 \mu 1$ of $10 \mathrm{mM}$ dNTP mixture, $0.5 \mu 1$ of recombinant RNasin ribonuclease inhibitor, $15 \mathrm{U}$ of AMV reverse transcriptase, $0.5 \mu \mathrm{g}$ Oligo $(\mathrm{dT})_{15}$ primer and nuclease-free water were added to a $20 \mu \mathrm{l}$ volume reaction. The mix was incubated at $42^{\circ} \mathrm{C}$ for $1 \mathrm{~h}$, heated at $95^{\circ} \mathrm{C}$ for $5 \mathrm{~min}$ and incubated at $4^{\circ} \mathrm{C}$ for 5 min. cDNA (50-100 ng) was amplified using primers specific for rat iNOS, TLR4 and $\beta$-actin. Primer sequences and optimal PCR annealing temperatures and cycle numbers are listed in Table I. PCR was performed for 35 cycles according to the following procedure: $94^{\circ} \mathrm{C}$ for $40 \mathrm{sec}$, annealing temperature for $40 \mathrm{sec}$ and $72^{\circ} \mathrm{C}$ for $40 \mathrm{sec}$. PCR products were subjected to $1.5 \%$ agarose gel electrophoresis and semi-quantified by optical density (OD) with an Image Pro Plus software computer program (Ipwin 32, Media Cybernetics, L.P., Bethseda, MD, USA). RNA expression was quantified by comparison with internal-control $\beta$-actin. 
Table I. Primer sequences, optimal PCR annealing temperatures and cycle numbers.

\begin{tabular}{lclc}
\hline Gene & Annealing temperature $\left({ }^{\circ} \mathrm{C}\right)$ & \multicolumn{1}{c}{ Primer } \\
\hline iNOS & 50 & $\begin{array}{l}\text { Forward: 5'-ATCCCGAAACGCTACACTT-3' } \\
\text { Reverse: 5'-AATCCACAACTCGCTCCA-3' }\end{array}$ \\
TLR4 & 55 & Forward: 5'-AAGAGCCGGAAAGTTATTGTGGTG-3' \\
& & Reverse: 5'-GGGTTTTAGGCGCAGAGTTTTGTA-3' \\
$\beta$-actin & 57 & Forward: 5'-GATATCGCTGCGCTCGTCGTC-3' & 358 \\
& & Reverse: 5'-GTCCCGGCCAGCCAGGTCCAG-3' \\
\hline
\end{tabular}

iNOS, inducible nitric oxide synthase; TLR4, Toll-like receptor 4.

Western blot analysis. Following incubation, cells were lysed. Protein content was determined using the BCA Protein Assay kit. A $20 \mu \mathrm{l}$ sample of PMФ lysate (20 $\mu \mathrm{g}$ protein) was separated on $12 \%$ SDS-PAGE and electroblotted onto a nitrocellulose membrane. The membrane was incubated overnight with diluted rabbit polyclonal iNOS antibody (1:1,000), followed by incubation with HRP-conjugated anti-rabbit $\operatorname{IgG}(1: 10,000)$. The $\beta$-actin antibody was used as a control for protein loading. Immunoreactive proteins were detected by chemiluminescence and quantified using imaging densitometry.

Immunofluorescence flow cytometry. PMФ were resuspended in FACS wash buffer (PBS, 5\% BSA and $0.05 \%$ sodium azide) and incubated with anti-TLR4 $\mathrm{mAb}$ for $1 \mathrm{~h}$ in $4^{\circ} \mathrm{C}$. After three washes with PBS, fluorescein isothiocyanate (FITC)-conjugated goat anti-mouse IgG antibody was added to test cell surface molecule TLR4. After washing with PBS for three times, the labeled cells were immediately detected using a FACS Calibur (Becton-Dickinson, San Diego, CA, USA). Analysis of 10,000 lymphocyte events per tube was performed using WinMDI software (Joseph Trotter, Scripps Research Institute, La Jolla, CA, USA).

Statistical analysis. Data are expressed as the means \pm SEM. Significant differences between groups were determined by one-way analysis of variance (ANOVA). $\mathrm{P}<0.05$ was considered to indicate a statistically significant difference.

\section{Results}

TGF- $\beta 1$ suppresses LPS-induced NO production in PMФ from CIA rats. The NO mediator has an important role in the inflammatory process. To examine how TGF- $\beta 1$ regulates the production and expression of this mediator, the levels of secreted NO were measured with a commercial kit. According to the literature and our previous study, TGF- $\beta 1$ at the concentration of $5 \mathrm{ng} / \mathrm{ml}$ for $36 \mathrm{~h}$ was incubated with PMФ from CIA rats stimulated by LPS (3 $\mu \mathrm{g} / \mathrm{ml})$ (19). As shown in Fig. 1, the secretion of NO in the PMФ of the model CIA group was significantly enhanced compared with that in the normal group following stimulation with $3 \mu \mathrm{g} / \mathrm{ml}$ LPS for $36 \mathrm{~h}$. The production of NO in the TGF- $\beta 1(5 \mathrm{ng} / \mathrm{ml})$ group was markedly decreased compared with the model group.

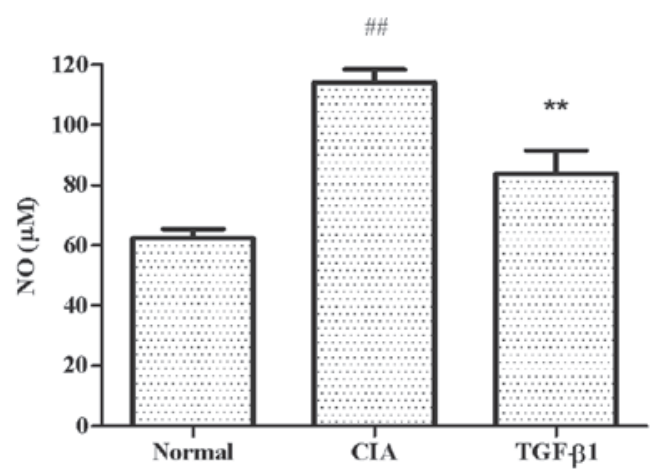

Figure 1. Effect of TGF- $\beta 1$ on LPS-induced NO production in PMФ from CIA rats. The concentration of $\mathrm{NO}$ was determined with a NO assay kit. Values are expressed as the means \pm SEM for five replicates in each group. Compared with normal group, ${ }^{\# \#} \mathrm{P}<0.01$; compared with CIA group, ${ }^{* *} \mathrm{P}<0.01$. TGF- $\beta 1$, transforming growth factor- $\beta 1$; LPS, lipopolysaccharide; NO, nitric oxide; PMФ, peritoneal macrophages; CIA, collagen-induced arthritis.

Inhibitory effect of TGF- $\beta 1$ on the production of NO was not due to its cytotoxicity. To examine whether the inhibitory effect of TGF- $\beta 1$ on the production of NO was due to its cytotoxicity, PMФ from CIA rats were incubated with 2-10 $\mu \mathrm{M}$ TGF- $\beta 1$ for $48 \mathrm{~h}$. The MTT assay reflects the metabolic activity of cells and serves as a helpful indicator of cell viability. As demonstrated in Fig. 2, within our tested TGF- $\beta 1$ concentrations, during the assessed times, the cell viability of PMФ from CIA rats was unaffected by TGF- $\beta 1$ compared with the vehicle control group. The results demonstrated that there was no cytotoxic effect of TGF- $\beta 1$ on PM $\Phi$ from CIA rats observed at the concentration of $5 \mathrm{ng} / \mathrm{ml}$ for $36 \mathrm{~h}$, thus the inhibitory effect of TGF- $\beta 1$ on the production of NO was not due to its cytotoxicity.

TGF- $\beta 1$ suppresses iNOS protein expression in $P M \Phi$ from $C I A$ rats. To understand how TGF- $\beta 1$ participates in the LPS-stimulated secretion of NO in PMФ from CIA rats, the effect of TGF- $\beta 1$ on the gene and protein expression of iNOS were investigated. As shown in Fig. 3A, iNOS mRNA expression increased significantly in the model CIA group compared with the normal group. However, treatment with TGF- $\beta 1(5 \mathrm{ng} / \mathrm{ml})$ for $36 \mathrm{~h}$ markedly inhibited the LPS-induced iNOS mRNA expression in the PMФ from the CIA rats. Fig. 3B illustrates that iNOS protein expression increased significantly 


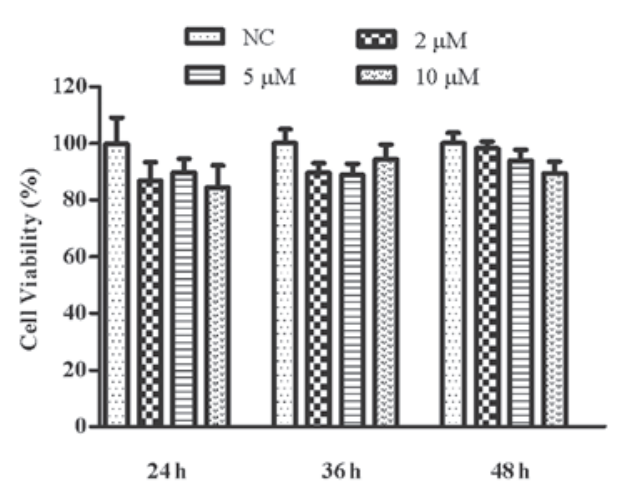

Figure 2. Effect of TGF- $\beta 1$ on cell cytotoxicity of PMФ from CIA rats. MTT assay was used to indicate cell viability. Values are expressed as the means \pm SEM for five replicates in each group. TGF- $\beta 1$, transforming growth factor- $\beta 1 ; \mathrm{PM} \Phi$, peritoneal macrophages; CIA, collagen-induced arthritis.

in the РМФ of the model group compared with the normal group. When the PM $\Phi$ from the CIA rats were incubated with TGF- $\beta 1(5 \mathrm{ng} / \mathrm{ml})$ for $36 \mathrm{~h}$ under the stimulation of LPS, the iNOS protein expression was downregulated.

Involvement of the LPS-TLR4 pathway in the inhibitory effect of TGF- $\beta 1$ on PM from CIA rats. To further understand the effect of TGF- $\beta 1$ on the PМФ obtained from the CIA rats, we investigated the effect of TGF- $\beta 1$ on the LPS-TLR4 signaling pathway. As shown in Fig. 4A, the expression of TLR4 mRNA in the PM $\Phi$ of the model CIA group was significantly enhanced compared with that in the normal group following stimulation with $3 \mu \mathrm{g} / \mathrm{ml}$ LPS for $36 \mathrm{~h}$. However, when PMФ was incubated with TGF- $\beta 1(5 \mathrm{ng} / \mathrm{ml})$, the expression of TLR4 mRNA in the PM $\Phi$ of the model CIA group was markedly suppressed. Fig. 4B reveals that the treatment of РМФ from CIA rats with LPS $(3 \mu \mathrm{g} / \mathrm{ml})$ caused a substantial increase in the expression of TLR4, but TGF- $\beta 1(5 \mathrm{ng} / \mathrm{ml})$ resulted in the inhibition of TLR4 expression on the surface of the PMФ from the CIA rats.

\section{Discussion}

Macrophages, present in all tissues of the human body, are segregated into resident tissue macrophages and inflammatory macrophages. Tissue macrophages normally assist in guarding against invading pathogens and regulating tissue remodeling in the local microenvironment (20). With the appropriate stimuli, inflammatory macrophages differentiate from circulating monocytes and accumulate in large numbers at sites of inflammation. They may infiltrate damaged tissues and cause further tissue injury $(21,22)$. Macrophages are involved in stimulating the adaptive immune system by processing and presenting antigens. Furthermore, they are key regulators of the innate immune defense against microbial infections, which is involved in the secretion of pro-inflammatory mediators and phagocytic activities (23). Previous studies have revealed that RA is characterized by the presence of large numbers of highly activated macrophages and anti-arthritic drugs may function by inhibiting macrophages $(18,24)$.

Although the role of TGF- $\beta 1$ in suppressing the macrophages of normal mice or rats has been well

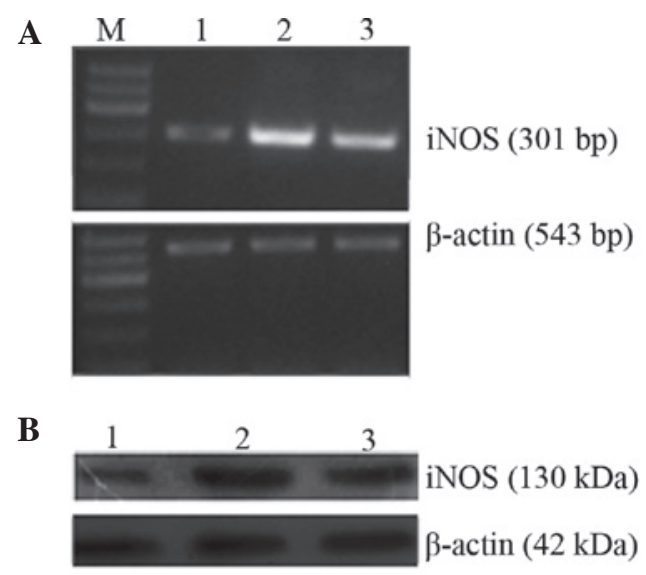

Figure 3. (A) Effects of TGF- $\beta 1$ on LPS-induced iNOS mRNA expression in РМФ from CIA rats. РМФ were divided into groups: 1, normal group; 2 , model CIA group; 3 , TGF- $\beta 1$ ( $5 \mathrm{ng} / \mathrm{ml})$ group. РМФ was stimulated by LPS $(3 \mu \mathrm{g} / \mathrm{ml})$ with or without TGF- $\beta 1(\mathrm{ng} / \mathrm{ml})$ for $36 \mathrm{~h}$. iNOS mRNA expression in $\mathrm{PM} \Phi$ was then detected by RT-PCR. Experiments were repeated three times. (A) Represents one of the results. (B) Effects of TGF- $\beta 1$ on LPS-induced iNOS protein expression in PMФ from CIA rats. PMФ were divided into groups: 1 , normal group; 2 , model CIA group; 3 , TGF- $\beta 1(5 \mathrm{ng} / \mathrm{ml})$ group. PMФ was stimulated by LPS $(3 \mu \mathrm{g} / \mathrm{ml})$ with or without TGF- $\beta 1(5 \mathrm{ng} / \mathrm{ml})$ for $36 \mathrm{~h}$. iNOS protein expression in PMФ was then detected by western blot analysis. Experiments were repeated three times. (B) Represents one of the results. TGF- $\beta 1$, transforming growth factor- $\beta 1$; LPS, lipopolysaccharide; iNOS, inducible nitric oxide synthase; PMФ, peritoneal macrophages; CIA, collagen-induced arthritis; RT-PCR, reverse transcription-polymerase chain reaction.

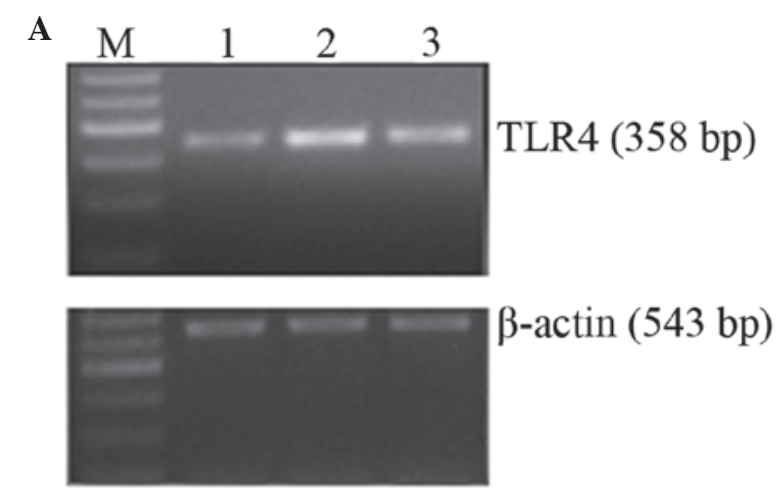

B

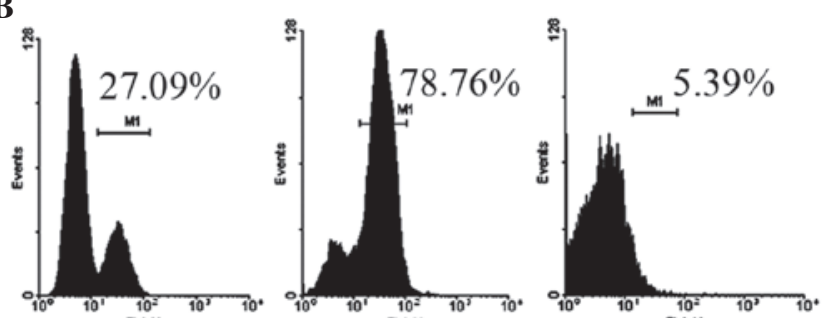

Figure 4. (A) Effects of TGF- $\beta 1$ on LPS-induced TLR4 mRNA expression in PМФ from CIA rats. РМФ were divided into groups: 1, normal group; 2 , model CIA group; 3 , TGF- $\beta 1(5 \mathrm{ng} / \mathrm{ml})$ group. РМФ was stimulated by LPS $(3 \mu \mathrm{g} / \mathrm{ml})$ with or without TGF- $\beta 1(5 \mathrm{ng} / \mathrm{ml})$ for $36 \mathrm{~h}$. TLR4 mRNA expression in PMФ was then detected by RT-PCR. Experiments were repeated three times. (A) Represents one of the results. (B) Effects of TGF- $\beta 1$ on LPSinduced TLR4 protein expression in PMФ from CIA rats. РМФ were divided into groups: 1, normal group; 2 , model CIA group; 3 , TGF- $\beta 1(5 \mathrm{ng} / \mathrm{ml})$ group. PMФ was stimulated by LPS $(3 \mu \mathrm{g} / \mathrm{ml})$ with or without TGF- $\beta 1(5 \mathrm{ng} / \mathrm{ml})$ for $36 \mathrm{~h}$. TLR4 protein expression in PM $\Phi$ was then detected by flow cytometry. Experiments were repeated three times. (B) Represents one of the results. TGF- $\beta 1$, transforming growth factor- $\beta 1$; LPS, lipopolysaccharide; iNOS, inducible nitric oxide synthase; $\mathrm{PM} \Phi$, peritoneal macrophages; CIA, collageninduced arthritis; RT-PCR, reverse transcription-polymerase chain reaction. 
documented $(25,26)$, little attention has been given to the effect of this cytokine under RA conditions. Previous studies have demonstrated that TGF- $\beta 1$ suppresses iNOS mRNA expression induced by LPS and IFN- $\gamma$ in macrophages $(27,28)$. RAW 264.7 cells expressing TGF- $\beta 1$ type II (T $\beta$ IIDN) [overexpressing a dominant negative TGF- $\beta 1$ receptor type II (T $\beta$ RIIDN) construct] have increased cytotoxic activity that is mediated by the upregulation of iNOS and TNF- $\alpha$ expression. Elevated iNOS and TNF- $\alpha$ levels, in association with IFN- $\gamma$, were detected in RAW-T $\beta$ RIIDN cells (29). TGF- $\beta 1-/-$ mice exhibited dysregulation of IFN $-\gamma$ signaling and high levels of iNOS expression and nitrite in the serum (30). In this study, TGF- $\beta 1$ suppressed LPS-induced NO secretion in the PMФ from CIA rats. Thus, the effect of TGF- $\beta 1$ on the production of NO by macrophages from inflammatory arthritis may be the same as that reported under non-inflammatory conditions.

$\mathrm{NO}$ is produced from the oxidation of $\mathrm{L}$-arginine in a reaction catalyzed by NO synthase (NOS), which has three major isoforms, constitutive neuronal NOS (NOS I or nNOS), inducible NOS (NOS II or iNOS) and constitutive endothelial NOS (NOS III or eNOS). nNOS and eNOS are constitutively expressed in various cells, releasing NO under physiological conditions and are involved in certain physiological functions, such as antimicrobial, anti-atherogenic, or apoptotic actions (31). However, aberrant iNOS expression may be induced by various proinflammatory agents, such as endotoxins (LPS) and cytokines (IL-1 $\beta$, TNF- $\alpha$ and INF- $\gamma$ ), in macrophages and other cell types. NO mediates diverse functions by acting on the majority of cells in the body through interactions with various molecular targets. Low NO concentration, following the induction of iNOS, possesses a beneficial role in the antimicrobial activity of macrophages against pathogens (32), whereas the excessive production of $\mathrm{NO}$ and its derivatives has been implicated in the pathogenesis of shock, inflammation and tissue damage (33). Our findings confirm these results, demonstrating that the mRNA and protein expression of iNOS in PM $\Phi$ from CIA rats was upregulated. TGF- $\beta 1$ significantly downregulates the expression of iNOS in PM $\Phi$ from CIA rats, so as to inhibit the production of $\mathrm{NO}$ and alleviate the NO-induced cytotoxic effect, which may be the mechanism of its protective effect.

TLRs are pattern recognition receptors expressed on the surface of monocytes and macrophages which recognize the specific patterns of microbial components, particularly those from pathogens, and regulate innate and adaptive immune responses (34). The TLR family consists of at least 13 members (TLR1-TLR13) in the mouse genome and 11 TLRs have been observed in humans. The ligands for the majority of TLRs have been identified. LPS, a component of the cell wall of gram-negative bacteria, activates macrophages by initiating binding to its receptor TLR4. TLR4 activates intracellular signaling pathways, including mitogen-activated protein kinases (MAPKs) and nuclear factor- $\kappa \mathrm{B}(\mathrm{NF}-\kappa \mathrm{B})$, by myeloid differentiation factor 88 (MyD88)-dependent and independent pathways (35). The transcription of a series of genes that encode pro-inflammatory cytokines, adhesion molecules and co-stimulatory molecules involved in the initiation or regulation of the inflammatory response were induced (36). To further investigate the possible mechanism by which TGF- $\beta 1$ modulates PM $\Phi$ from CIA rats, the involvement of LPS-TLR4 signaling pathway in the inhibitory effect of TGF- $\beta 1$ on PMФ from CIA rats was tested. The mRNA expression level of TLR4 in PMФ was analyzed using RT-PCR. The expression of TLR4 on the cell surface was detected using flow cytometry. Our results demonstrate that TLR 4 mRNA expression was increased in the PM $\Phi$ from the CIA rats with LPS stimulation. Moreover, the TLR4 protein on the cellular surface of the PMФ from the CIA rats was also increased. These findings are consistent with previous studies, in which blocking TLR4 in monocytes and macrophages stimulated with LPS resulted in the inhibition of TNF- $\alpha$ and NO production (37), suggesting that activation through the TLR4 pathway plays a role in inflammation in response to LPS. Nevertheless, TGF- $\beta 1$ demonstrated an effect on downregulating TLR4 expression in LPS-stimulated PМФ from CIA rats. Thus, the present study demonstrates that the inhibitory effect of TGF- $\beta 1$ on NO production is dependent on the TLR4 signaling pathway in LPS-stimulated PM $\Phi$ from CIA rats.

\section{Acknowledgements}

This study was funded by the Innovation Program of Shanghai Municipal Education Commission (no. 12YZ049), Shanghai Municipal Health Bureau Project (no. 2010296) and the Young Teacher Training Program in the Universities in Shanghai (jdy11046). The Opening Project of Shanghai Key Laboratory of Orthopaedic Implant (KFKT2011003) and the Excellent Young Development Program of Shanghai's Ninth Hospital also supported part of this work.

\section{References}

1. Govinden R and Bhoola KD: Genealogy, expression, and cellular function of transforming growth factor- $\beta$. Pharmacol Ther 98: 257-265, 2003.

2. Dubois CM, Laprise MH, Blanchette F, Gentry LE and Leduc R: Processing of transforming growth factor $\beta 1$ precursor by human furin convertase. J Biol Chem 270: 10618-10624, 1995.

3. Taylor AW: Review of the activation of TGF- $\beta$ in immunity. J Leukocyte Biol 85: 29-33, 2009.

4. Annes JP, Chen Y, Munger JS and Rifkin DB: Integrin $\alpha_{\mathrm{V}} \beta_{6}$-mediated activation of latent TGF- $\beta$ requires the latent TGF- $\beta$ binding protein-1. J Cell Biol 165: 723-734, 2004.

5. Annes JP, Munger JS and Rifkin DB: Making sense of latent TGF- $\beta$ activation. J Cell Sci 116: 217-224, 2003.

6. Nakamura K, Kitani A, Fuss I, Pedersen A, Harada N, Nawata H and Strober W: TGF- $\beta 1$ plays an important role in the mechanism of $\mathrm{CD} 4{ }^{+} \mathrm{CD} 25^{+}$regulatory $\mathrm{T}$ cell activity in both humans and mice. J Immunol 172: 834-842, 2004.

7. Chen ML, Yan BS, Bando Y, Kuchroo VK and Weiner HL: Latency-associated peptide identifies a novel $\mathrm{CD} 4^{+} \mathrm{CD} 25^{+}$ regulatory $\mathrm{T}$ cell subset with TGF $\beta$-mediated function and enhanced suppression of experimental autoimmune encephalomyelitis. J Immunol 180: 7327-7337, 2008

8. Li MO, Wan YY, Sanjabi S, Robertson AK and Flavell RA: Transforming growth factor- $\beta$ regulation of immune responses. Annu Rev Immunol 24: 99-146, 2006.

9. Wrzesinski SH, Wan YY and Flavell RA: Transforming growth factor- $\beta$ and the immune response: implications for anticancer therapy. Clin Cancer Res 13: 5262-5270, 2007.

10. McCartney-Francis NL and Wahl SM: Transforming growth factor- $\beta$ : a matter of life and death. J Leukocyte Biol 55: 401-409, 1994.

11. Shull MM, Ormsby I, Kier AB, et al: Targeted disruption of the mouse transforming growth factor- $\beta 1$ gene results in multifocal inflammatory disease. Nature 359: 693-699, 1992.

12. Kulkarni AB, Huh CG, Becker D, et al: Transforming growth factor- $\beta 1$ null mutation in mice causes excessive inflammatory response and early death. Proc Natl Acad Sci USA 90: 770-774, 1993. 
13. Walsh NC, Crotti TN, Goldring SR and Gravallese EM: Rheumatic diseases: the effects of inflammation on bone. Immunol Rev 208: 228-251, 2005.

14. Muñoz-Valle JF, Torres-Carrillo NM, Guzmán-Guzmán IP, et al: The functional class evaluated in rheumatoid arthritis is associated with soluble TGF- $\beta 1$ serum levels but not with G915C (Arg25Pro) TGF- 31 polymorphism. Rheumatol Int 32: 367-372, 2012.

15. Kim SY, Han SW, Kim GW, Lee JM and Kang YM: TGF- $\beta 1$ polymorphism determines the progression of joint damage in rheumatoid arthritis. Scand J Rheumatol 33: 389-394, 2004.

16. Lafyatis R, Thompson NL, Remmers EF, et al: Transforming growth factor- $\beta$ production by synovial tissues from rheumatoid patients and streptococcal cell wall arthritic rats. Studies on secretion by synovial fibroblast-like cells and immunohistologic localization. J Immunol 143: 1142-1148, 1989.

17. Mantel PY and Schmidt-Weber CB: Transforming growth factor- $\beta$ : recent advances on its role in immune tolerance. Methods Mol Biol 677: 303-338, 2011

18. Wang TY, Li J, Li CY, Jin Y, Lü XW, Wang XH and Zhou Q: Leflunomide induces immunosuppression in collagen-induced arthritis rats by upregulating $\mathrm{CD} 4^{+} \mathrm{CD} 25^{+}$regulatory T cells. Can J Physiol Pharm 88: 45-53, 2010.

19. Kim JS, Kim JG, Moon MY, Jeon CY, Won HY, Kim HJ, Jeon YJ, Seo JY, Kim JI, Kim J, Lee JY, Kim PH and Park JB: Transforming growth factor-betal regulates macrophage migration via RhoA. Blood 108: 1821-1829, 2006.

20. Henson PM and Riches DW: Modulation of macrophage maturation by cytokines and lipid mediators: a potential role in resolution of pulmonary inflammation. Ann NY Acad Sci 725: 298-308, 1994.

21. Grenier D and Grignon L: Response of human macrophage-like cells to stimulation by Fusobacterium nucleatum ssp. nucleatum lipopolysaccharide. Oral Microbiol Immunol 21: 190-196, 2006.

22. Yang N, Wu LL, Nikolic-Paterson DJ, et al: Local macrophage and myofibroblast proliferation in progressive renal injury in the rat remnant kidney. Nephrol Dial Transplant 13: 1967-1974, 1998

23. Takaki H, Minoda Y, Koga K, et al: TGF- $\beta 1$ suppresses IFN- $\gamma$-induced NO production in macrophages by suppressing STAT1 activation and accelerating iNOS protein degradation. Genes Cells 11: 871-882, 2006.

24. Rodenburg RJ, van Den Hoogen FH, Barrera P, van Venrooij WJ and van De Putte LB: Superinduction of interleukin $8 \mathrm{mRNA}$ in activated monocyte derived macrophages from rheumatoid arthritis patients. Ann Rheum Dis 58: 648-652, 1999.
25. Vodovotz Y: Control of nitric oxide production by transforming grow th factor- $\beta 1$ : mechanistic insights and potential relevance to human disease. Nitric Oxide 1: 3-17, 1997.

26. Jun CD, Choi BM, Kim SU, Lee SY, Kim HM and Chung HT: Down-regulation of transforming growth factor- $\beta$ gene expression by antisense oligodeoxynucleotides increases recombinant interferon- $\gamma$-induced nitric oxide synthesis in murine peritoneal macrophages. Immunology 85: 114-119, 1995.

27. Ding A, Nathan CF, Graycar J, Derynck R, Stuehr DJ and Srimal S: Macrophage deactivating factor and transforming growth factors- $\beta 1-\beta 2$ and $-\beta 3$ inhibit induction of macrophage nitrogen oxide synthesis by IFN- $\gamma$. J Immunol 145: 940-944, 1990.

28. Tsunawaki S, Sporn M, Ding A and Nathan C: Deactivation of macrophages by transforming growth factor- $\beta$. Nature 334: 260-262, 1988 .

29. Lee GT, Hong JH, Kwak C, Woo J, Liu V, Lee C and Kim IY: Effect of dominant negative transforming growth factor- $\beta$ receptor type II on cytotoxic activity of RAW 264.7, a murine macrophage cell line. Cancer Res 67: 6717-6724, 2007.

30. McCartney-Francis NL and Wahl SM: Dysregulation of IFN- $\gamma$ signaling pathways in the absence of TGF- $\beta 1$. J Immunol 169: 5941-5947, 2002.

31. Bogdan C, Röllinghoff $M$ and Diefenbach A: The role of nitric oxide in innate immunity. Immunol Rev 173: 17-26, 2000.

32. Cook HT and Cattell V: Role of nitric oxide in immune-mediated diseases. Clin Sci (Lond) 91: 375-384, 1996.

33. Wang JX, Hou LF, Yang Y, Tang W, Li Y and Zuo JP: SM905, an artemisinin derivative, inhibited NO and pro-inflammatory cytokine produced by suppressiong MAPK and NF- $\mathrm{KB}$ pathways in RAW 264.7 macrophages. Acta Pharmacol Sin 30: 1428-1435, 2009.

34. Uematsu S and Akira S: Toll-like receptors and innate immunity. J Mol Med 9: 712-725, 2006

35. Kawai T, Takeuchi O, Fujita T, et al: Lipopolysaccharide stimulates the MyD88-independent pathway and results in activation of IFN-regulatory factor 3 and the expression of a subset of lipopolysaccharide-inducible genes. J Immunol 167: 5887-5894, 2001.

36. Takeda $\mathrm{K}$ and Akira S: Toll-like receptors in innate immunity. Int Immunol 17: 1-14, 2005.

37. Chávez-Sánchez L, Chávez-Rueda K, Legorreta-Haquet MV, et al: The activation of CD14, TLR4, and TLR2 by mmLDL induces IL-1 $\beta$, IL-6, and IL-10 secretion in human monocytes and macrophages. Lipids Health Dis 9: 117, 2010. 